\title{
Development of a Digital Control Unit to Displace Diesel Fuel With Natural Gas
}

Federal Manufacturing \& Technologies

\author{
A. D. Talbott
}

KCP-613-5913

PEC

Mat 1 :

OS:

Published March 1997

Final Report/Project Accomplishments Summary CRADA Number 96-KCP-1039

Approved for public release; distribution is unlimited.

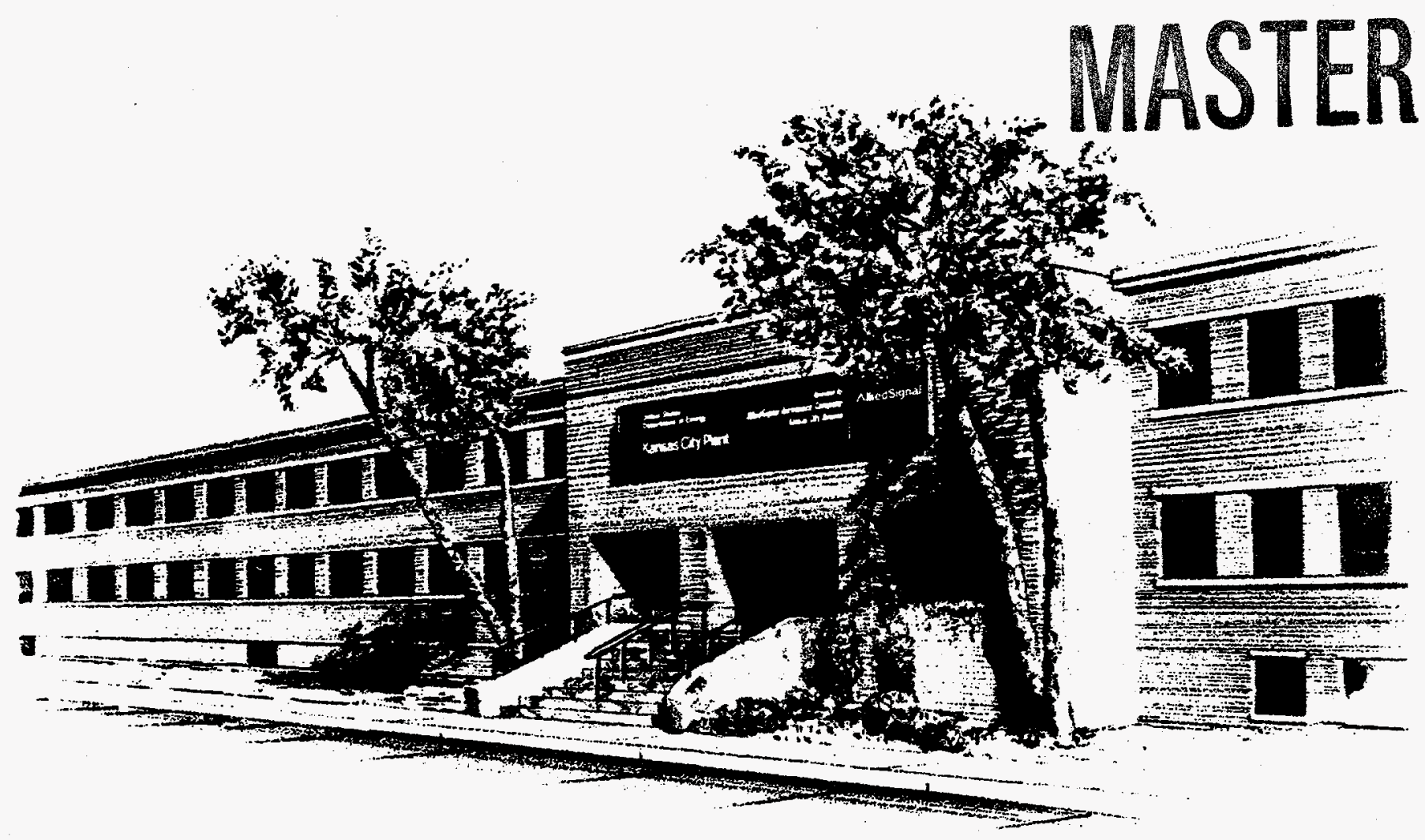

DISTRIBUTION OF THIS DOCUMENT IS UNLIMITED

Prepared Under Contract Number DE-ACO4-76-DP00613 for the United States Department of Energy 


\section{DISCLAIMER}

This report was prepared as an account of work sponsored by an agency of the United States Government. Neither the United States Government nor any agency thereof, nor any of their employees, makes any warranty, express or implied, or assumes any legal liability or responsibility for the accuracy, completeness, or usefulness of any information, apparatus, product, or process disclosed, or represents that its use would not infringe privately owned rights. Reference herein to any specific commercial product, process, or service by trade names, trademark, manufacturer, or otherwise, does not necessarily constitute or imply its endorsement, recommendation, or favoring by the United States Government or any agency thereof. The views and opinions of authors expressed herein do not necessarily state or reflect those of the United States Government or any agency thereof.

Printed in the United States of America.

This report has been reproduced from the best available copy.

Available to DOE and DOE contractors from the Office of Scientific and Technical Information, P. O. Box 62, Oak Ridge, Tennessee 37831; prices available from (615) 576-8401, FTS 626-8401.

Available to the public from the National Technical Information Service, U. S. Department of Commerce, 5285 Port Royal Rd., Springfield, Virginia 22161.

A prime contractor with the United States Department of Energy under Contract Number DE-ACO4-76-DP00613.
AlliedSignal Inc. Federal Manufacturing \& Technologies P. O. Box 419159 Kansas City, Missouri 64141-6159 
KCP-613-5913

Distribution Category UC-700

Approved for public release; distribution is unlimited.

DEVELOPMENT OF A DIGITAL CONTROL UNIT TO DISPLACE DIESEL FUEL WITH NATURAL GAS

A. D. Talbott

Published March 1997

Final Report/Project Accomplishments Summary

CRADA Number 96-KCP-1039 


\section{DISCLAMMER}

Portions of this document may be illegible in electronic image products. Images are produced from the best available original document. 


\section{DISCLAIMER}

This report was prepared as an account of work sponsored by an agency of the United States Government. Neither the United States Government nor any agency thereof, nor any of their employees, make any warranty, express or implied, or assumes any legal liability or responsibility for the accuracy, completeness, or usefulness of any information, apparatus, product, or process disclosed, or represents that its use would not infringe privately owned rights. Reference herein to any specific commercial product, process, or service by trade name, trademark, manufacturer, or otherwise does not necessarily constitute or imply its endorsement, recommendation, or favoring by the United States Government or any agency thereof. The views and opinions of authors expressed herein do not necessarily state or reflect those of the United States Government or any agency thereof. 


\section{DEVELOPMENT OF A DIGITAL CONTROL UNIT TO DISPLACE DIESEL FUEL WITH NATURAL GAS \\ Project Accomplishments Summary CRADA Number 96-KCP-1039}

Date: $1 / 28 / 97$

Revision: 0

\section{A. Parties}

The project is a relationship between

AlliedSignal FM\&T

Full Circle Engineering

2000 E $95^{\text {th }}$ Street

P.O. Box 335716

P.O. Box 419159

Northglenn, CO 80233

Kansas City, MO 64141-6159

\section{B. Background}

Full Circle Engineering (FCE), supported by the Colorado School of Mines (CSM), proposed a Small Business CRADA with AlliedSignal Federal Manufacturing \& Technologies/Kansas City (FM\&T/KC) for the development of a fumigation digital control unit (DCU) that would allow the displacement of diesel fuel with natural gas.

Nationwide, diesel trucks and buses consumed over 21 billion gallons of fuel in 1992. The development of systems that allow the use of alternative fuels, natural gas in particular, for transportation would significantly reduce emissions and pollutants. It would also help implement DOE's mandate for energy security (use of domestic fuels) required by the Energy Policy Act (EPACT).

Dual-fuel, or fumigation technology, allows natural gas to displace a portion (in theory over $90 \%$ ) of the diesel fuel used in large truck and bus engines. This technology introduces clean burning natural gas to fleet operators as an alternative to pure diesel fuel. Fumigation is economically attractive to fleet operators if $70 \%$ or more of the diesel is displaced with lower cost natural gas. At this high level of displacement, detonation in the engine cylinders may occur. This is caused by the burning fuel/air mixture compressing unburned portions of the cylinder charge, causing them to burn violently or explode, creating large stresses in the cylinder. This technology is especially important for vehicles used in high altitude locations because altitude is known to have a major impact on heavy duty engine power output and emissions.

This CRADA effort was expected to enhance FM\&T/KC's electronics and interfacing design capabilities as well as to expand design skills in 
microprocessor-based systems, severe environmental testing, and sensor interfacing. The experience gained on this project would have been valuable on any future work in test equipment design involving microprocessors, chassis interfacing, and overall system architecture.

It was expected that a collaborative design team effort between FM\&T/KC and FCE would develop an engine control and fuel management system that significantly lowers emissions and eliminates detonation. This would allow natural gas fumigation to be economically attractive to heavy duty vehicle and fleet operators in the absence of any tax incentives or emissions credits.

\section{Description}

The project scope was for FM\&T/KC and FCE to develop a digital control unit for a fumigation system that would have high diesel fuel displacement with natural gas, low emissions, and safe and economic engine operation. FCE, with the assistance of the Colorado Institute for Fuels and High Altitude Engine Research (CIFER), would have determined the emission measurements to be performed as a function of engine operation and diesel displacement. FM\&T/KC would have designed the digital control unit system based on the FCE controller specifications. Once a prototype DCU had been built, the unit would have been tested and analyzed at FCE facilities.

Because FCE went out of business shortly after the CRADA was signed, the project was terminated.

\section{Expected Economic Impact}

Had this project come to full completion as scheduled, it is anticipated that Full Circle Engineering (FCE) would have gained a technological advantage in the area of dual-fuel automotive controllers. This would have helped to market their business in the high altitude Colorado region by providing efficient alternate fuel for heavy duty vehicle conversions. The energy industry also would have benefited with greater engine efficiencies for dual-fuel vehicles, thus making it more economically feasible to convert diesel engines. Lastly, the impact would have been felt by the taxpayers. A significant increase in fuel economy and decreased emissions from engines using the new fumigation technology would have been seen. In the long term, alternative fuel technologies such as fumigation would lessen the United States' dependency on foreign sources of oil by using this country's abundant supply of natural gas.

\section{E. Benefits to DOE}

Had this project come to full completion as scheduled, it is anticipated that this project would have benefited DOE programs by increasing the core technical capabilities in the areas of microprocessor systems design and external sensor 
interfacing. This new work would have added to the overall technical expertise of the Test Equipment organization at FM\&T/KC, because test systems developed at FM\&T/KC grow more electronically complex as production unit complexity is increased. Future test equipment design must keep up with all new developments in electronics to maintain the capability to test any part produced in the weapons complex. Because FM\&T/KC is the consolidated manufacturing site for the nuclear weapons complex, there must be sufficient test equipment design knowledge to be able to electronically test any new weapons production unit.

\section{F. Industry Area}

The heavy duty vehicle and energy industries would have benefited from the use of dual-fuel automotive controllers.

\section{G. Project Status}

Terminated because Full Circle Engineering went out of business shortly after the CRADA was signed.

\section{H. Point of Contact for Project Information}

Ken Bauer

US Department of Energy

Kansas City Area Office

PO Box 410202

Kansas City, MO 64141-0202

Telephone: (816) 997-3917

Fax: (816) 997-5059
Duane Talbott

AlliedSignal FM\&T

PO Box 419159

Kansas City, MO 64141-6159

Telephone: (816) 997-5666

Fax (816) 997-7169

\section{Company Size and Point of Contact}

Size of Company: Small Business

Point of contact:

Eric Nilsson

13847 W 65th Drive

Arvada, CO 80004

\section{J. Project Examples}

Not applicable

\section{K. Technology Commercialization}

Not applicable 


\section{Release of Information}

I have reviewed the attached Project Accomplishment Summary prepared by AlliedSignal FM\&T and agree that the information about our CRADA may be released for external distribution.

So Rind FiE lice Presckent

Name:

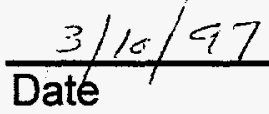

Organization:

Title: 